\title{
PENGEMBANGAN KAWASAN BUDIDAYA RUMPUT LAUT BERBASIS ANALISA KESESUAIAN LAHAN DI PERAIRAN NURUWE
}

\author{
(Development of Seaweed Yields Based on Analyze Land Suitability \\ in Nuruwe Waters)
}

\author{
Valentine D. Saleky ${ }^{1 *}$, Semuel F. Tuhumury ${ }^{2}$, W. Waileruny ${ }^{3}$ \\ ${ }^{1)}$ Mahasiswa Program Studi Magister Ilmu Kelautan Pascasarjana Universitas Pattimura \\ 2) Jurusan Budidaya Perairan Fakultas Perikanan dan Ilmu Kelautan, Universitas Pattimura \\ 3) Jurusan Pemanfaatan Sumberdaya Perikanan Fakultas Perikanan dan Ilmu Kelautan, Universitas Pattimura \\ valentinesaleky16@gmail.com,sftuhumury@yahoo.co.id,wimwaileruny11@gmail.com \\ Corresponding author*
}

\begin{abstract}
ABSTRAK: Perairan Nuruwe merupakan perairan oseanis dan juga perairan dengan potensi perikanan yang cukup melimpah serta terdapat potensi wisata baik dalam wisata alam maupun wisata budidaya. Tujuan dari penelitian ini adalah 1) menganalisis karakteristik parameter fisika-kimia sebagai faktor pembatas kesesuaian lokasi budidaya rumput laut di perairan Nuruwe, serta 2) menganalisis kesesuaian lahan budidaya rumput laut berdasarkan kriteria kesesuaian lahan dan menentukan luasan lahan budidaya. Metode pengambilan data parameter lingkungan perairan dengan teknik random sampling. Analisis data yang digunakan adalah analisis spasial untuk menentukan kesesuaian lahan menggunakan GIS berdasarkan kriteria kelayakan budidaya rumput laut dan analisis daya dukung. Berdasarkan hasil penelitian diperoleh parameter kualitas air yang diukur layak atau sesuai untuk mendukung kegiatan budidaya sistem longline di perairan Nuruwe. Kesesuaian lahan budidaya rumput laut dengan sistem longline di perairan Nuruwe tergolong sesuai (S2). Luasan lahan yang efektif sebesar \pm 10 ha dengan jumlah sebanyak 20 unit longline.
\end{abstract}

Kata Kunci: Kesesuaian lahan, budidaya, daya dukung, rumput laut, perairan Nuruwe

ABSTARCT: The Nuruwe waters are oceanic waters with a considerable amount of fisheries resources and a potential for tourism in natural and aquaculture tourism. This research aimed to analyze the characteristics of the physical and chemical parameters as a limiting factor for the site selection of seaweed cultivation in Nuruwe waters and analyze land suitability of seaweed cultivation based on its criteria and determine the area of cultivation. A random sampling technique was applied to the data collection of marine environmental parameters. Data were analyzed using a spatial analysis with GIS techniques and carrying capacity analysis. The spatial analysis was used to determine the land suitability of seaweed cultivation based on the site selection criteria. The results showed that water quality parameters were suitable to support seaweed cultivation with the longline system. The effective area is \pm 10 , with the number of longlines that can be placed as many as 20 units.

Keywords: Land suitability, aquaculture, carrying capacity, seagrass, Nuruwe waters 


\section{PENDAHULUAN}

Rumput laut merupakan komoditi ekspor yang sangat potensial saat ini (Fadli, $d k k$., 2017). Permintaan rumput laut sangat tinggi sebagai bahan baku pembuatan makanan, kosmetik, dan obat-obatan (Mira, 2012). Salah satu peluang dalam upaya meningkatkan kesejahteraan nelayan adalah budidaya rumput laut (Hikmah, 2015). Kegiatan budidaya ini dapat dilakukan oleh setiap orang dengan memiliki modal serta pengetahuan yang cukup. Hakekatnya, budidaya rumput laut bersifat mudah, prospek yang menjanjikan, meningkatkan ekonomi masyarakat dan daerah, cepat panen, serta menyerap tenaga kerja (Tangko, 2008). Dalam kenyataannya usaha budidaya rumput laut belum banyak berkembang, walaupun potensi wilayah pantai Indonesia yang membujur sepanjang 108.000 kilometer, mampu menyediakan areal yang sangat potensial untuk budidaya rumput laut. Berdasarkan laporan tahunan Kementerian Kelautan dan Perikanan (2018), potensi luas areal budidaya rumput laut saat ini tercatat 1,1 juta $\mathrm{Ha}$ atau 9\% dari seluruh luas kawasan potensial budidaya laut yang sebesar 12.123.383 Ha. Adapun tingkat pemanfaatannya diperkirakan baru mencapai $25 \%$.

Perairan Nuruwe, Kabupaten Seram Bagian Barat merupakan perairan oseanik dan memiliki potensi perikanan yang cukup melimpah. Selain memiliki potensi wisata, perairan Nuruwe dimanfaatkan sebagai lokasi budidaya rumput laut. Perkembangan produksi rumput laut di perairan Nuruwe meningkat saat musim timur, sebaliknya pada musim barat dengan kondisi perairan yang relatif tenang produksi biasanya menurun (Maryunus, $d k k$., 2018). Selanjutnya dikatakan bahwa produksi rumput laut di Nuruwe hanya berlangsung 3 kali dalam setahun. Produksi rumput laut tertinggi di perairan Nuruwe mencapai 96 ton pada tahun 2009 dan terendah pada tahun 2006-2007 sebesar 24 ton. Namun seiring dengan waktu, kegiatan budidaya rumput laut sudah sangat berkurang bahkan dapat dikatakan sudah tidak ada. Hasil pemanfaatan rumput laut melalui budidaya tidak sejalan dengan menafat ekonomi yang diterima masyarakat.
DOI: https://doi.org/10.30598/TRITONvol16issue1page38-51

Berbagai permasalahan yang muncul pada proses budidaya rumput laut antara lain biaya operasional yang semakin tinggi, kurangnya pengetahuan tentang teknologi terbaru, kondisi cuaca, minimnya perhatian dan bantuan untuk usaha tersebut (Nurwidodo, dkk., 2017; Sugandi \& Putra, 2017). Berbagai kendala dan masalah yang timbul di Desa Nuruwe selain masalah misum, terdapat juga konflik pemanfaatan lahan, permasalahan sosial ekonomi dan budaya, kendala keterbatasan lahan, serta permasalahan teknologi. Berbagai masalah yang muncul tersebut dikarenakan pemerintah desa, masyarakat serta pihak terkait lainnya tidak memperhitungkan dan membuat kajian secara tepat untuk pengembangan kawasan budidaya rumput laut. Salah satu aspek yang sangat penting yang kurang diperhatikan adalah kesesuaian lahan untuk pengembangan budidaya dengan mempertimbangkan kondisi karakteristik perairan. Luasan lahan yang sesuai untuk budidaya berdasarkan karakteristik parameter fisik kimia sebagai faktor pembatas belum dijadikan sebagai dasar pengambilan keputusan. Padahal, karakteristik parameter fisik kimia merupkan basis pengambilan keputusan suatu kawasan dapat dikembangkan atau tidak sebagai lokasi budidaya rumput laut. Tujuan dari penelitian ini yaitu: 1) menganalisis karakteristik parameter fisika-kimia sebagai faktor pembatas kesesuaian lokasi budidaya rumput laut di perairan Nuruwe, serta 2) menganalisis kesesuaian lahan budidaya rumput laut berdasarkan kriteria kesesuaian lahan dan menentukan luasan lahan budidaya.

\section{METODE PENELITIAN}

Penelitian ini dilakukan di Perairan Nuruwe, Kabupaten Seram Bagian Barat yang berlangsung selama bulan februari sampai maret 2020 (Gambar 1). Kegiatan ini meliputi beberapa tahapan yaitu survei lokasi, pengambilan atau pengumpulan data lapangan, penyusunan basis data, analisa data di laboratorium. Penentuan titik sampling parameter kualitas lingkungan perairan dilakukan dengan menggunakan teknik sistematik random sampling. Teknik pengambilan data dengan cara mengukur 
parameter lingkungan fisik kimia pada setiap stasiun pengamatan meliputi suhu, salinitas, $\mathrm{DO}, \mathrm{pH}$, nitrat, fosfat, kekeruhan, TSS, arus, gelombang, kecerahan perairan, ammonia, minyak, dan deterjen. Analisis laboratorium digunakan untuk menganalisis parameter fisikakimia perairan yang tidak dapat diukur secara insitu antara lain DO, nitrat, fosfat, kekeruhan, TSS, ammonia, minyak, dan deterjen. Amarullah (2007) menjelaskan bahwa kelas kesesuaian lahan perairan budidaya dibedakan pada tingkat kelas dan didefeniskan sebagai berikut:

1. Kelas S1: Sangat Sesuai (Highly suitable), yaitu apabila lahan atau kawasan yang sangat sesuai untuk budidaya rumput laut tanpa adanya faktor pembatas yang berarti dimana parameter-parameter fisika, kimia dan biologi perairan memenuhi persyaratan/ketentuan yang ideal, atau memiliki faktor pembatas yang bersifat minor dan tidak akan menurunkan produktivitasnya secara nyata terhadap kegiatan atau produksi hasil. Lahan kelas S1 memiliki nilai sebesar 99-135 dari nilai maksimum peruntukan budidaya rumput laut.
2. Kelas 2: Sesuai Bersyarat (Moderately Suitable), yaitu apabila lahan atau kawasan mempunyai pembatas (penghambat) yang serius/agak besar yang berpengaruh mengurangi aktivitas/produktivitas rumput laut dan keuntungan serta meningkatkan masukkan yang diperlukan, dimana parameter-parameter fisika, kimia dan biologi perairan sedikit memenuhi persyaratan / ketentuan yang ideal. Didalam pengelolaannya diperlukan tambahan masukan (input) teknologi dan tingkatan perlakuan. Lahan kelas S2 memiliki nilai sebesar 62-98 dari nilai maksimum peruntukan budidaya rumput laut.

3. Kelas 3-N: Tidak Sesuai (Not Suitable), yaitu lahan atau kawasan yang tidak sesuai diusahakan untuk budidaya rumput laut yang lestari karena mempunyai faktor pembatas yang berat/bersifat permanen dimana parameterparameter fisika, kimia dan biologi perairan tidak memenuhi persyaratan/ketentuan yang ideal. Lahan kelas S3 memliki nilai $<61$ dari nilai maksimum peruntukan budidaya rumput laut.

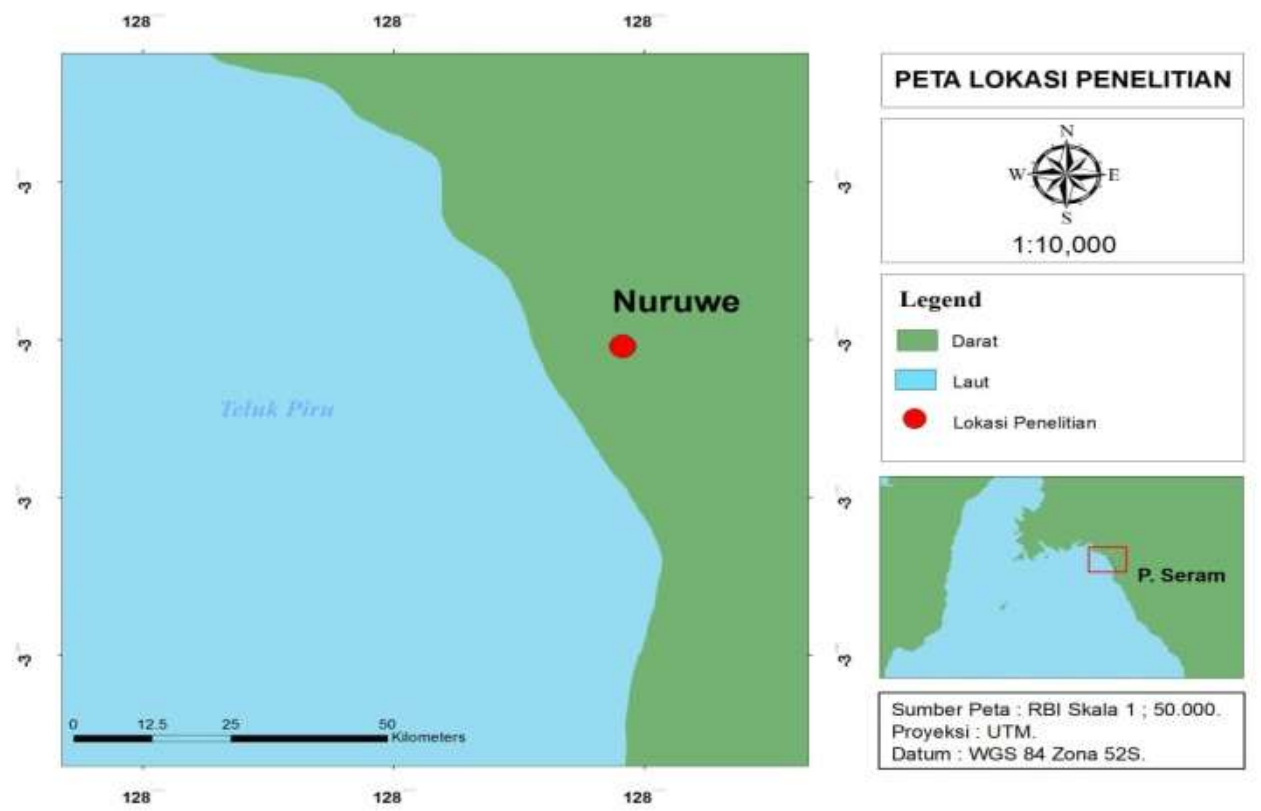

Gambar 1. Peta Lokasi Penelitian 
Kesesuaian lahan untuk budidaya rumput laut dianalisis menggunakan kriteria parameter dan matriks, skor dan bobot sistem penilaian kesesuaian lahan disajikan pada Tabel 1 . Sedangkan untuk menganalisis daya dukung lingkungan menggunakan formula yang dikemukanan oleh Soselisa (2006) danm Amarulah (2007) dengan menggunakan rumus sebagai berikut:

$$
\text { Daya Dukung }=D \times \frac{L K L}{L U M}
$$

Ket:

LKL : Luas Kapasitas Kesesuaian Lahan

LUM : Luas Unit Metode

D : Koefisien Budidaya Efektif (60\%)

\section{HASIL DAN PEMBAHASAN}

\section{Parameter Kualitas Perairan}

\section{Suhu}

Berdasarkan hasil penelitian diperoleh suhu perairan Nuruwe homogen yaitu $30^{\circ} \mathrm{C}$. Hasil ini menunujukkan bahwa perairan tersebut layak diperuntukkan untuk budidaya rumput laut jenis Eucheuma cottonii. Kandungan suhu
Perairan Nuruwe pada peta analisis kesesuaian kandungan suhu (Gambar 2), menunjukkan bahwa keenam stasiun pengamatan memiliki nilai suhu yang optimal dan homogen. Menurut Akib et al (2015), perairan yang mendukung untuk budidaya rumput laut Eucheuma cottoni yang baik adalah suhu dengan rata-rata $29,33^{\circ} \mathrm{C}$ sampai $30,3^{\circ} \mathrm{C}$.

\section{Kecerahan}

Kecerahan merupakan parameter yang berhubungan erat dengan besarnya penetrasi cahaya dalam perairan. Energi yang berasal dari sinar matahari dibutuhkan oleh thallus rumput laut dalam mekanisme fotosintesis. Disisi lain, penetrasi cahaya menjadi rendah ketika tingginya kandungan partikel tersuspensi di perairan dekat pantai, akibat aktivitas pasang surut dan juga tingkat kedalaman (Hutabarat \& Evans, 2008 dalam Gufana, S.S. et al., 2017). Parameter kecerahan Perairan Nuruwe pada peta tematik kecerahan (Gambar 3), menunjukkan bahwa keenam stasiun pengamatan memiliki nilai kecerahan yang optimal yaitu pada setiap stasiun mencapai $12 \mathrm{~m}$.

Tabel 1. Kriteria Kelayakan Lokasi Untuk Budidaya Rumput Laut

\begin{tabular}{|c|c|c|c|c|c|c|c|c|}
\hline No & Parameter & Bobot & Kategori S1 & Skor & $\begin{array}{l}\text { Kategori } \\
\text { S2 }\end{array}$ & Skor & $\begin{array}{c}\text { Kategori } \\
\text { S3 }\end{array}$ & Skor \\
\hline 1 & Suhu $\left({ }^{0} \mathrm{C}\right)$ & 1 & $27-30$ & 5 & $\begin{array}{c}25-<27 \text { atau } \\
>30-32\end{array}$ & 3 & $<25$ atau $>32$ & 1 \\
\hline 2 & Salinitas (\%o) & 1 & $29-33$ & 5 & $\begin{array}{c}25-<29 \text { atau } \\
>33-37\end{array}$ & 3 & $<25$ atau $>37$ & 1 \\
\hline 3 & DO (mg/l) & 2 & $>4$ & 5 & $2-4$ & 3 & $<2$ & 1 \\
\hline 4 & Nitrat (mg/l) & 3 & $0.01-0.7$ & 5 & $0.8-1.0$ & 3 & $<0.01$ atau $>1$ & 1 \\
\hline 5 & Fosfat (mg/l) & 3 & $0.2-0.5$ & 5 & $\begin{array}{c}0.1-0.2 \mathrm{atau} \\
0.5-1\end{array}$ & 3 & $<0.1$ dan $>1$ & 1 \\
\hline 6 & Kekeruhan (mg/l) & 2 & $\leq 10,0$ & 5 & $>10,0-\leq 40,0$ & 3 & $>40,0$ & 1 \\
\hline 7 & TSS (mg/l) & 2 & $<25$ & 5 & $25-50$ & 3 & $>50$ & 1 \\
\hline 8 & Ammonia (mg/l) & 2 & $<0,3$ & 5 & 0,3 & 3 & $>0,3$ & 1 \\
\hline 9 & $\mathrm{pH}$ & 1 & $7-8,5$ & 5 & $\begin{array}{c}6,6-<7 \text { atau } \\
>8,5-9,5\end{array}$ & 3 & $<6,5$ atau $>9,5$ & 1 \\
\hline 10 & Gelombang (m) & 2 & $0-0,025$ & 5 & $0,26-0,5$ & 3 & $>0,5$ & 1 \\
\hline 11 & Minyak & 2 & Tidak ada & 5 & Sedang & 3 & Tercemar & 1 \\
\hline 12 & Deterjen & 2 & Tidak ada & 5 & Sedang & 3 & Tercemar & 1 \\
\hline 13 & $\begin{array}{l}\text { Kecepatan arus } \\
(\mathrm{cm} / \mathrm{s})\end{array}$ & 2 & $20-40$ & 5 & $\begin{array}{c}10-19 \text { atau } 41- \\
50\end{array}$ & 3 & $<10$ atau $<50$ & 1 \\
\hline 14 & Kecerahan (m) & 2 & $>5$ & 5 & $3-5$ & 3 & $<3$ & 1 \\
\hline
\end{tabular}

Sumber : Modifikasi dari Ariyati dkk, (2007) dan Amarullah (2007).

Ket : Skor 5 : Sangat Sesuai ( nilai parameter pada kategori S1), Skor 3 : Sesuai (nilai parameter pada kategori S2), Skor $1:$ Tidak Sesuai (nilai paraeter pada kategori S3) 


\section{Kekeruhan}

Lokasi budidaya di perairan Nuruwe memiliki nilai kekeruhan berkisar antara 0,050,08 NTU (Gambar 4), termasuk dalam kategori sangat sesuai. Lokasi dengan nilai kekeruhan yang tinggi harus dihindari untuk aktivitas budidaya. Kekeruhan yang tinggi yang diakibatkan oleh suspended solids tidak sesuai untuk kegiatan budidaya rumput laut. Hal ini akan mengurangi penetrasi cahaya yang masuk ke dalam air sehingga menutup permukaan thallus dan menghambat absorbsi nutrien melalui permukaan thallus (Vairappan and Chung, 2006 dalam Adipu et al., 2013).

\section{TSS (Total Suspended Solid)}

Kandungan TSS perairan dari tiap stasiun pengamatan yang diperoleh, berkisar antara 3,6$7,4 \mathrm{mg} / \mathrm{l}$ (Gambar 5). Berdasarkan analisa kesesuaian, menunjukkan bahwa kandungan TSS di perairan Nuruwe berada pada kriteria sangat sesuai untuk lokasi budidaya rumput laut, karena padatan tersuspensi yang baik untuk usaha budidaya laut berkisar antara $<25 \mathrm{ppm}$ (KLH, 1988 dalam Khasanah, 2013). TSS adalah endapan yang menghasilkan kekeruhan sehingga menghalangi cahaya matahari untuk fotosintesis (Risnawati, $d k k ., 2018$ ).

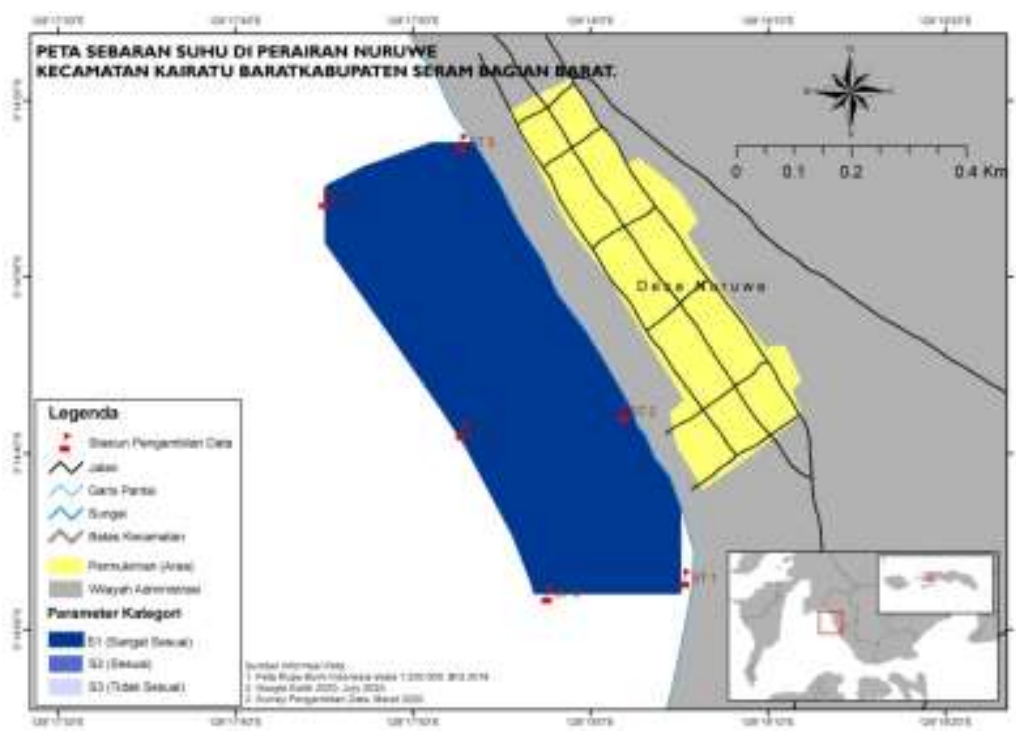

Gambar 2. Peta analisa kesesuaian suhu

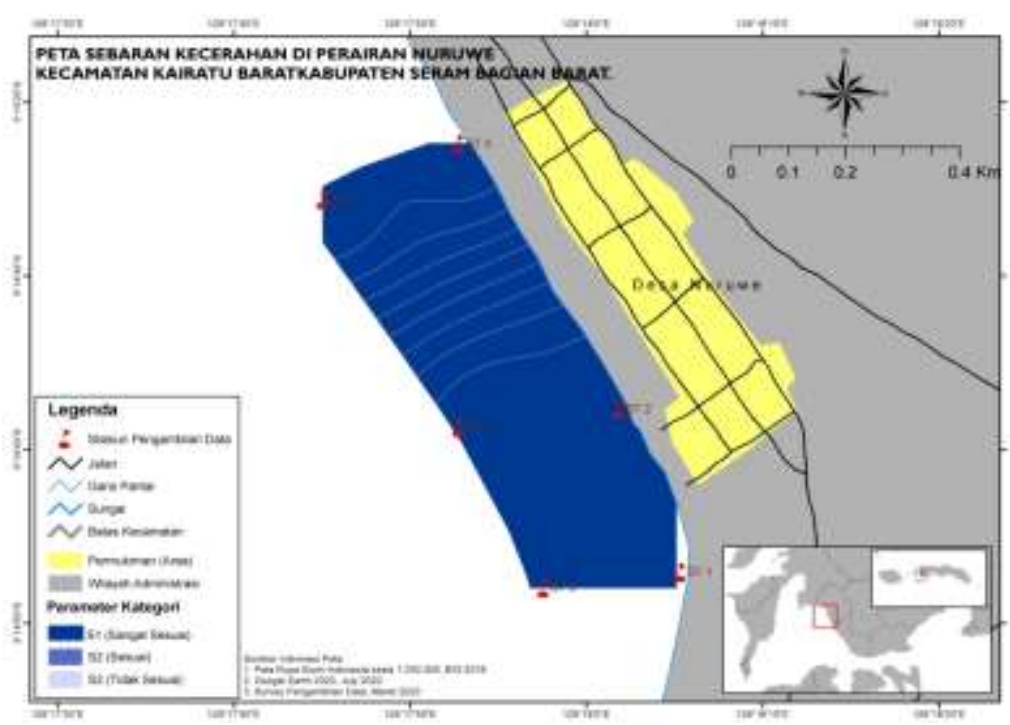

Gambar 3. Peta analisa kesesuaian kecerahan 


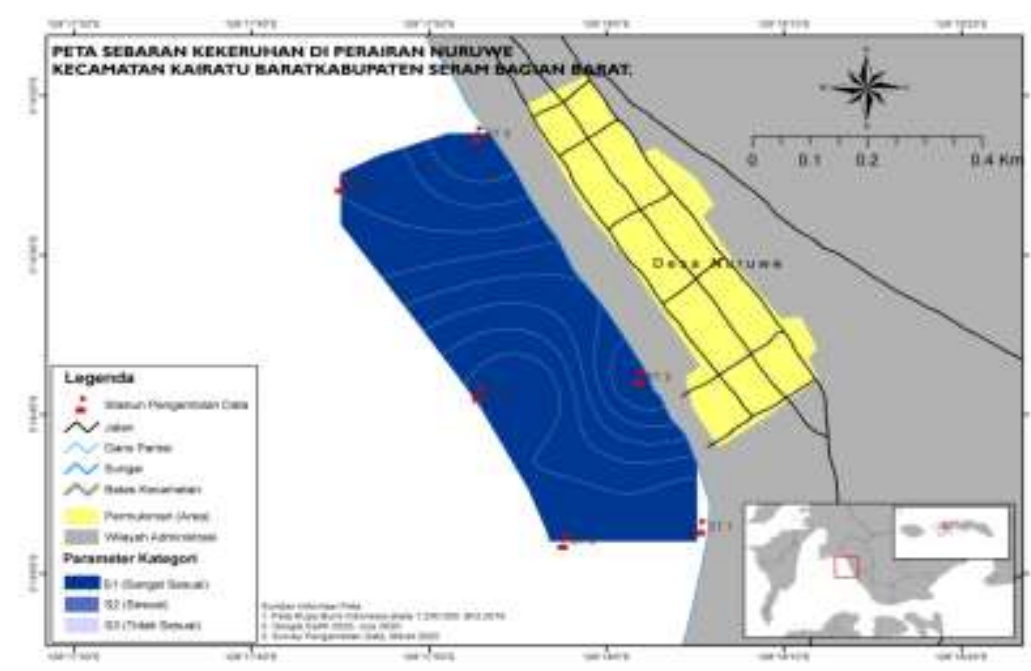

Gambar 4. Peta analisa kesesuaian kekeruhan

\section{Arus}

Nilai kisaran kecepatan arus di perairan Nuruwe termasuk homogen yaitu $26 \mathrm{~cm} / \mathrm{s}$ atau $0,26 \mathrm{~m} / \mathrm{s}$ (Gambar 6). Hasil ini menunjukkan bahwa nilai kecepatan arus masih tergolong ideal untuk budidaya rumput laut dengan sistem long line. Jika gerakan air bagus akan membawa nutrien yang cukup dan dapat mencuci kotorankotoran halus yang menempel pada thallus. Menurut Anggadireja et al., (2006), kecepatan arus yang baik untuk budidaya rumput laut berkisar $0,2-0,4 \mathrm{~m} / \mathrm{s}$

\section{Gelombang}

Berdasarkan morfologi Perairan Nuruwe, maka perairan ini merupakan perairan oseanik yang relatif terbuka karena terhadap terjangan ombak dan gelombang terutama pada musim barat. Berdasarkan pada tingkat keterlindungan, maka perairan dikategorikan dalam tingkat kelayakan rendah (Gambar 7). Faktor keterlindungan merupakan faktor penting dan beresiko dalam kegiatan budidaya rumput laut (Schaduw \& Ngangi, 2015). Menurut Pongmasak $d k k$., (2010), pengembangan usaha budidaya perikanan pesisir berbasis budidaya laut dapat dilakukan pada kawasan pesisir seperti selat, teluk, laguna, yang terlindung dari pengaruh arus kuat, gelombang besar, angin yang kencang serta bebas cemaran. Parameter gelombang Perairan Nuruwe pada peta tematik gelombang (Gambar 6), menunjukkan bahwa keenam stasiun pengamatan memiliki nilai gelombang yang sesuai (S2) untuk krtiteria budidaya rumput laut karena kisaran gelombang yang didapat selama penelitian yaitu $0,2-0,3$ $\mathrm{m} / \mathrm{s}$.

\section{Salinitas}

Dalam proses budidaya rumput laut snagat dipengaruhi oleh salinitas karena berhubungan dengan tekanan osmotik (Risnawati, dkk., 2018). Menurut Schaduw \& Ngangi (2015), jenis $K$. alvarezii merupakan jenis yang stenohaline dan tidak tahan terhadap salinitas yang tinggi. Menurut Anggadiredja et al. (2006) bahwa salinitas untuk pertumbuhan rumput laut Eucheuma sp. yang optimal berkisar antara 28$33 \%$. Hasil yang diperoleh di perairan Nuruwe relatif sama yaitu 33\%, sehingga termasuk dalam kategori sangat sesuai (S1) (Gambar 8). 


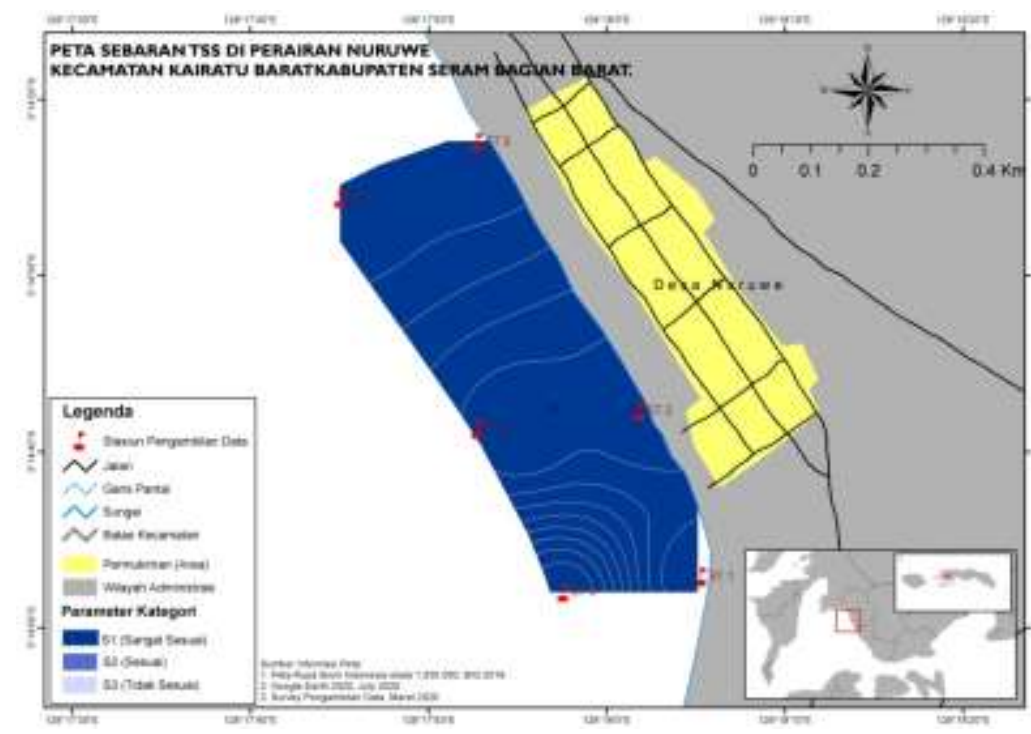

Gambar 5. Peta analisis kesesuaian TSS

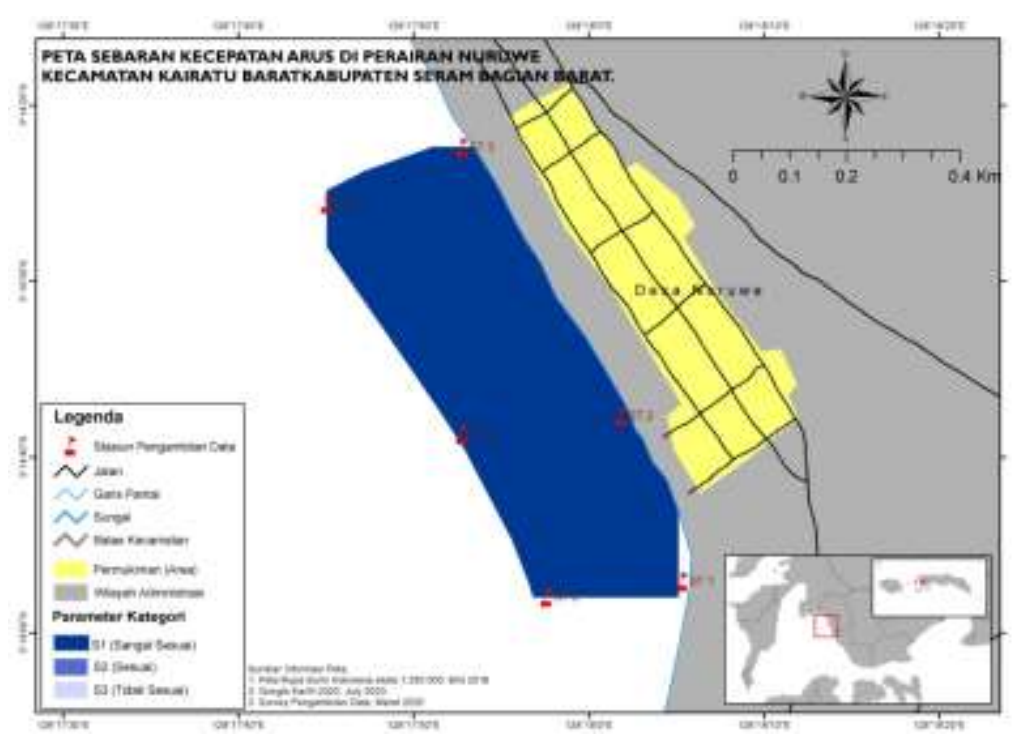

Gambar 6. Peta analisis kesesuaian arus

\section{DO (Dissolved Oxygen)}

Nilai oksigen perairan berkisar antara 7,6 mg/l-9,8 mg/l. Kandungan oksigen terlarut (DO) pada kawasan perairan Nuruwe termasuk kaya oksigen. Nilai kandungan oksigen terlarut ini secara umum dapat dikatakan lebih besar bila dibandingkan dengan kandungan oksigen terlarut yang ditetapkan dalam Keputusan Menteri Negara Lingkungan Hidup No. 51 Tahun 2004 yaitu 5 mg/l. Kandungan oksigen terlarut Perairan Nuruwe sangat sesuai untuk pertumbuhan organisme laut termasuk rumput laut (Gambar 9). Secara umum, oksigen diperlukan oleh biota perairan untuk kelangsungan hidupnya. Dalam proses fotosintesis yang menghasilkan oksigen terlarut di perairan sangat dibutuhkan karbondioksida yang merupakan hasil dari aktivitas biota perairan. Hal tersebut menunjukkan pentingnya oksigen terlarut dalam proses budidaya rumput laut. 


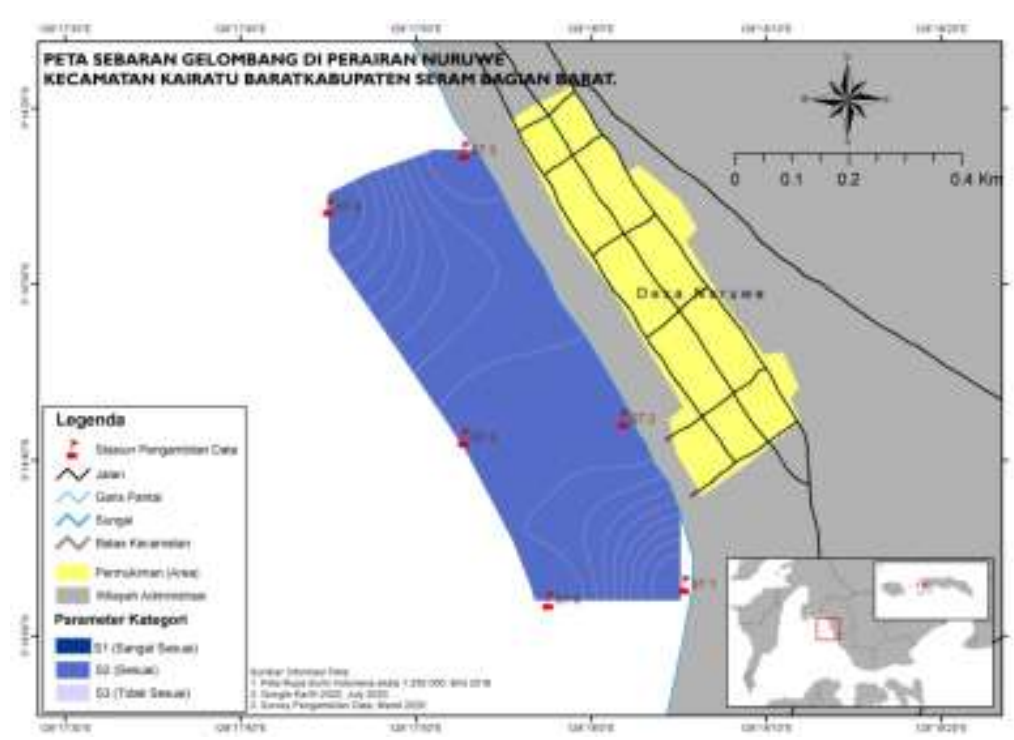

Gambar 7. Peta analisa kesesuaian gelombang

\section{Nitrat $\left(\mathrm{NO}_{3}\right)$}

Kondisi perairan untuk budidaya rumput laut haruslah subur, kaya akan unsur hara sebagai makanan rumput laut. Salah satu unsur hara yang penting dan dibutuhkan untuk pertumbuhan rumput laut adalah nitrat. Dalam penelitian ini, kandungan nitrat di perairan Nuruwe relatif sama yaitu berkisar 0,0-0,01 $\mathrm{mg} / \mathrm{l}$ dan termasuk dalam kategori tidak sesuai (S3) (Gambar 10). Kandungan nitrat yang rendah diduga disebabkan oleh penyerapan nitrat oleh ekosistem mangrove, selain itu juga arus yang mengangkut nutrien ke daerah lain. Nitrat yang tinggi juga mempengaruhi pertumbuhan rumput laut. Diketahui bahwa tinggi nitrat di perairan dapat dipengaruhi oleh masukan dari daratan yang bersumber dari kegiatan masyarakat (Risnawati, $d k k$., 2018). Nitrat yang tinggi akan menimbulkan ledakan fitoplasnkton beracun yang berbahaya bagi sumberdaya dan lingkungan perairan. pada kedalaman-kedalaman tertentu dapat Konsentrasi nitrat bervariasi menurut letak geografis dan kedalaman. Nitrat di lapisan bawah lebih dikontrol oleh sirkulasi air lapisan bawah dan proses mineralisasi nitrogen organik partikulat. Massa air bawah yang kaya akan nutrien dapat ditransportasikan melalui proses up welling. Di lain sisi, nitrat akan diambil di lapisan permukaan selama proses produktifitas primer. Dengan demikian, bila terjadi sedikit peningkatan konsentrasi nitrat maka fitoplankton dengan efektif akan memanfaatkan nitrat untuk fotosintesis (Ulqodry et al. 2010).

\section{Fosfat $\left(\mathrm{PO}_{4}\right)$}

Seperti halnya nitrat, fosfat juga merupakan nutrien yang diperlukan sebagai vitamin bagi pertumbuhan rumput laut. Konsentrasi fosfat tertinggi dengan nilai 44,065 $\mathrm{mg} / \mathrm{l}$, dan terendah 24,605 mg/l (Gambar 11). Fosfat sendiri dalam perairan berperan sebagai nutrien, akan tetapi tingginya kandungan fosfat di perairan dapat berdampak pada ledakan plankton (Kangkan, 2006 dalam Borolla 2011). Banyaknya nutrient di perairan secara tidak langsung dapat menyebabkan timbulnya penyakit ice-ice pada rumput laut. Faktor perubahan kondisi lingkungan melalui perubahan parameter lingkungan memicu timbulnya penyakit ini (Santoso \& Nugraha, 2008).

\section{1. pH (Derajat Keasaman)}

Proses fotosintesis akan mengurangi konsentrasi karbondioksida di perairan maka dari itu, dengan berkurangnya konsentrasi karbondioksida khususnya karbondioksida yang mengandung asam seperti asam karbonat, mengakibatkan $\mathrm{pH}$ lebih tinggi ketika terjadi fotosintesis (Kangkan, 2006 dalam Ramdhan et al, 2016). Hasil pengamatan $\mathrm{pH}$ Perairan Nuruwe berada pada kisaran 6,4-6,9 (Gambar 12). Hasil ini menunjukkan bahwa $\mathrm{pH}$ di 
perairan Nuruwe masih dalam kisaran yang menunjang untuk pertumbuhan rumput laut. Gufran et al. (2007) dalam Burase et al, (2013) menyatakan bahwa budidaya perairan akan berhasil baik pada $\mathrm{pH}$ berkisar 6,5-9,0.

\section{Ammonia $\left(\mathrm{NH}_{3}\right)$}

Ammonia merupakan hasil proses dekomposisi benda-benda organik. Ditemukannya ammonia bebas dalam air menunjukkan adanya pencemaran oleh kotoran binatang dan manusia. Hasil pengamatan menunjukkan nilai kandungan ammonia tertinggi berada pada stasiun 5 yaitu $0,34 \mathrm{mg} / \mathrm{l}$ dan nilai kandungan ammonia terendah berada pada stasiun pertama yaitu $0,25 \mathrm{mg} / \mathrm{l}$ (Gambar 13). Keberadaan ammonia di perairan berhubungan dengan nitrat. Proses nitrifikasi yang dilakukan oleh bakteri merupakan proses penyusunan senyawa nitrat dari senyawa ammonia.

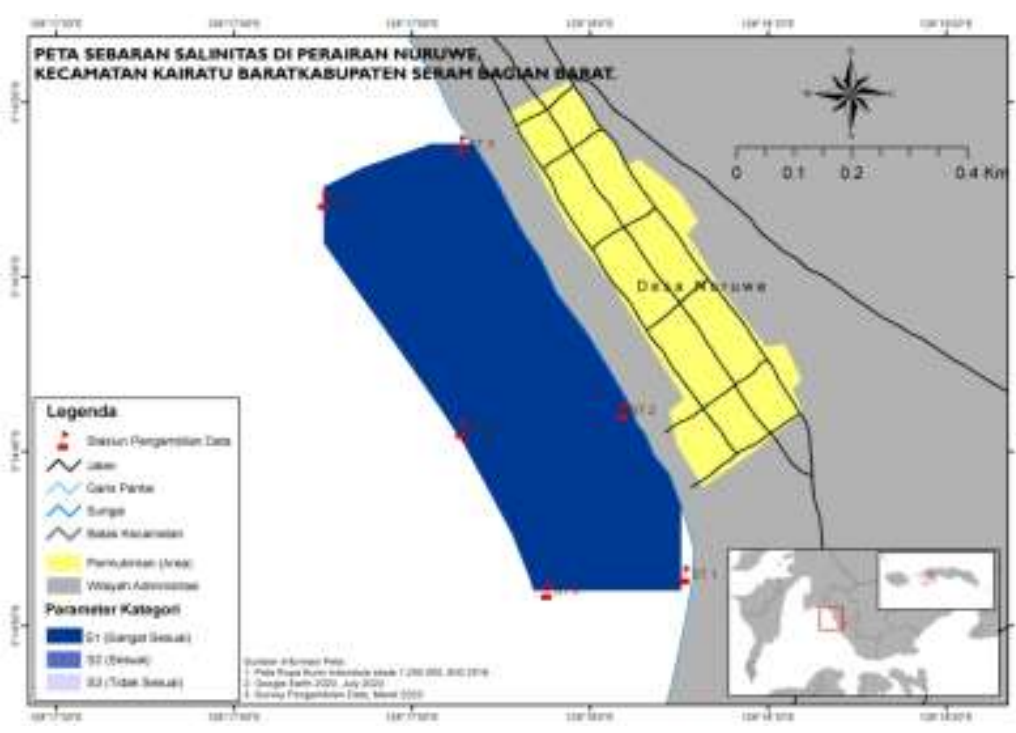

Gambar 8. Peta analisa kesesuaian salinitas

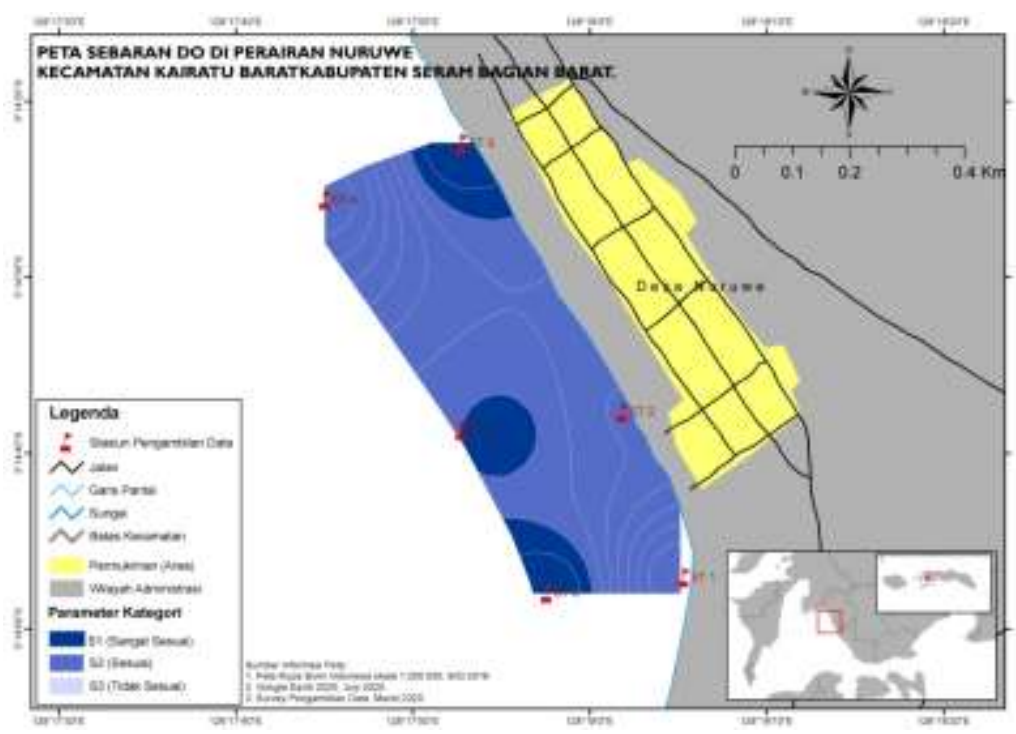

Gambar 9. Peta analisa kesesuaian DO 


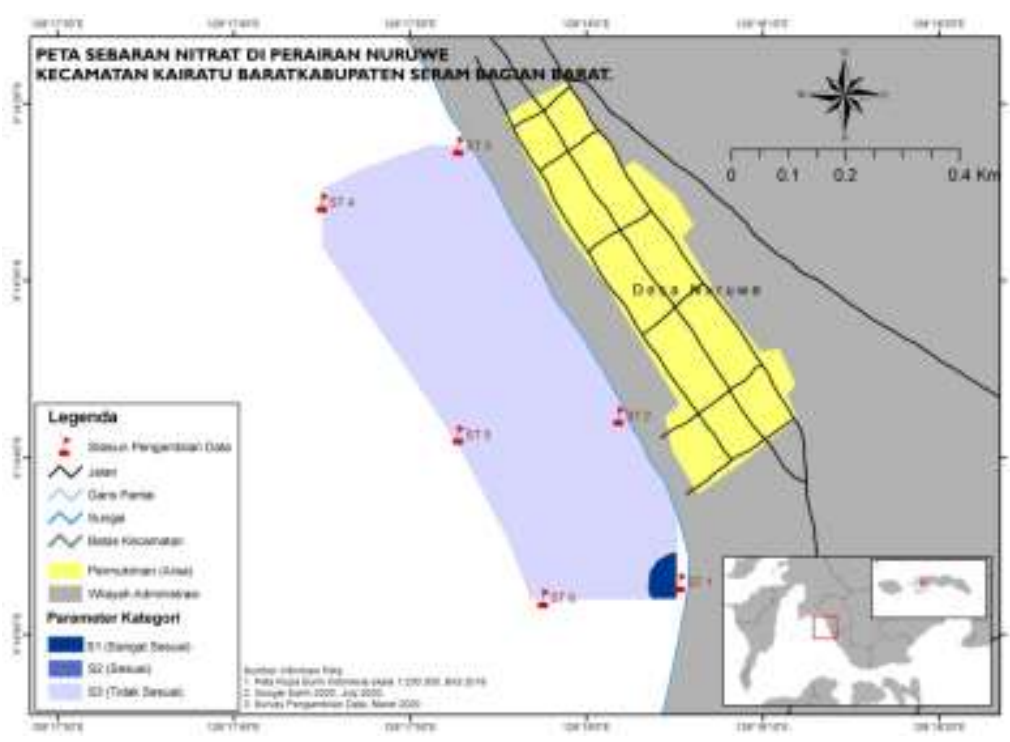

Gambar 10. Peta analisa kesesuaian nitrat

\section{Minyak}

Minyak merupakan bahan organik bersifat tetap dan sukar diuraikan bakteri. Limbah ini membuat lapisan pada permukaan air sehingga membentuk selaput. Berat jenisnya lebih kecil dari air sehingga minyak tersebut membentuk lapisan tipis di permukaan air dan menutupi permukaan. Akibatnya, oksigen yang masuk dalam air akan terbatas. Reaksi dengan kimia pada suhu tertentu akan mengakibatkan dekomposisi dengan karbon, oksigen, dan hidrogen (Ginting, 2007 dalam Maufilda, 2015). Hasil pengukuran kadar minyak di Perairan Nuruwe masih tergolong relatif rendah atau baik untuk budidaya rumpu laut yaitu 0,01580,02598 dan masih dalam kategori sangat sesuai (S1) (Gambar 14).

\section{Deterjen}

Hasil pengamatan menunjukkan kandungan deterjen di perairan Nuruwe relatif sama yaitu 0,0. Hasil ini menunjukkan kadar deterjen rendah atau ideal sehingga perairan Nuruwe cocok untuk dilakukan budidaya rumput laut (Gambar 15). Tingkat pencemaran Perairan Nuruwe termasuk kategori rendah sehingga diduga kandungan alginat pada rumput laut yang ada termasuk baik. Kandungan alginat semakin kecil seiring meningkatnya konsentrasi deterjen sehingga alginat merupakan metabolit primer terbentuk mengikuti pertumbuhan dari rumput laut tersebut. Pertumbuhan rumput laut yang paling baik akan menghasilkan kandungan alginat yang baik pula (Bountyfa et al, 2012).

\section{Kesesuaian Lahan Perairan Nuruwe}

Hasil evaluasi/analisis kesesuaian lahan menunjukkan dari parameter-parameter biofisik kimia perairan menghasilkan dua kategori kesesuaian lahan yaitu sesuai dan tidak sesuai. Kategori sesuai dengan luasan 16,927 ha atau $69 \%$ dan tidak sesuai dengan luasan 7,731 ha atau 31\% (Gambar 16). Dalam pengembangan usaha budidaya perlu mempertimbangkan areal pemanfaatannya seperti arus lalu lintas (pelayaran), jarak antar unit dan perlindungan ekosistem lainnya seluas $40 \%$ dari luas lahan yang layak (6,7708 ha). Berdasarkan pertimbangan tersebut maka ditentukan luas efektif lahan perairan untuk digunakan dalam kegiatan budidaya rumput laut adalah luasan lahan sesuai (16,927 ha) akan dikurangi pemanfaatan lainnya $(6,7708$ ha). Dengan demikian maka luas lahan yang efektif untuk pengembangan budidaya rumput laut dengan sistem longline sebesar 10,1562 ha atau \pm 10 ha (60\% dari lahan yang layak). Jumlah unit longline untuk pengembangan budidaya rumput laut dengan mempertimbangkan luas tiap unit longline, jarak antar unit longline dan arus pelayaran, maka jumlah unit longline dengan 50 x 50 meter yang dapat dioperasikan secara efektif adalah 10,1562 ha dengan jumlah 20 unit longline. 


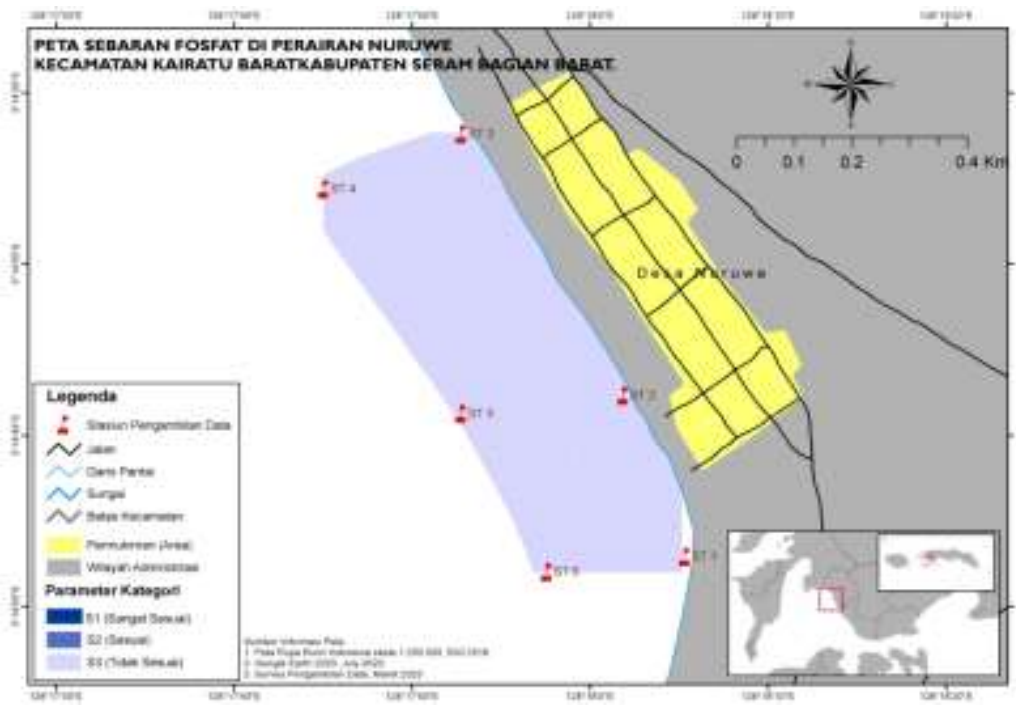

Gambar 11. Peta analisis kesesuaian fosfat

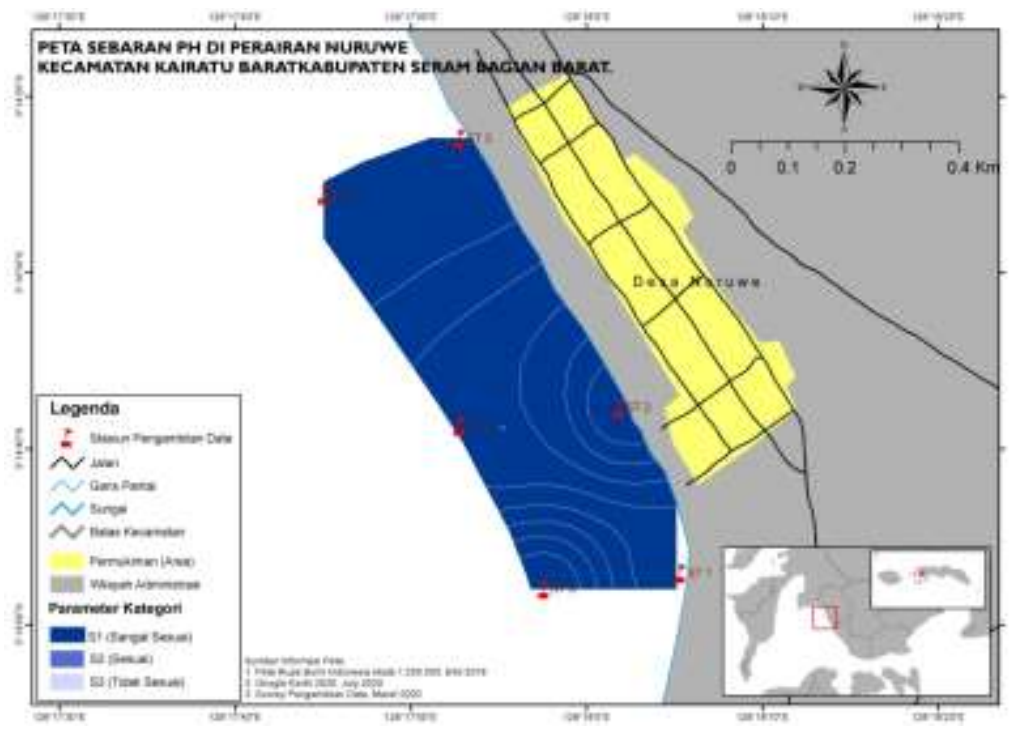

Gambar 12. Peta analisa kesesuaian $\mathrm{pH}$

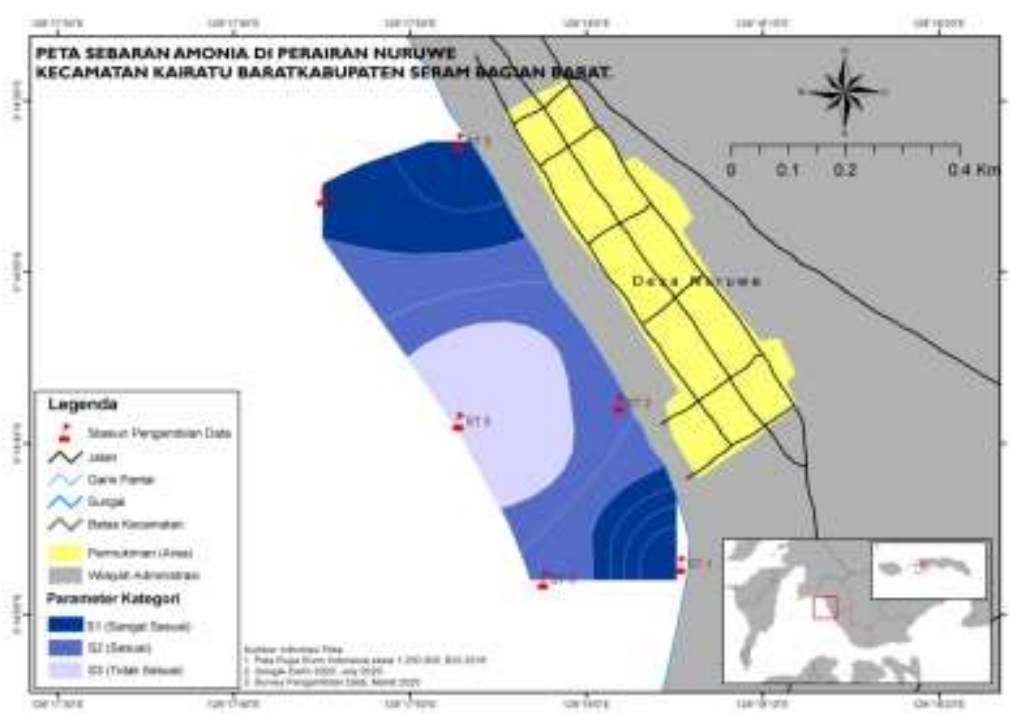

Gambar 13. Peta analisa kesesuaian ammonia 
JUrnal TRITON Volume 16, Nomor 1, April 2020, hal. $38-51$

P-ISSN 1693-6493 E-ISSN 2656-2758

DOI: https://doi.org/10.30598/TRITONvol16issue1page38-51

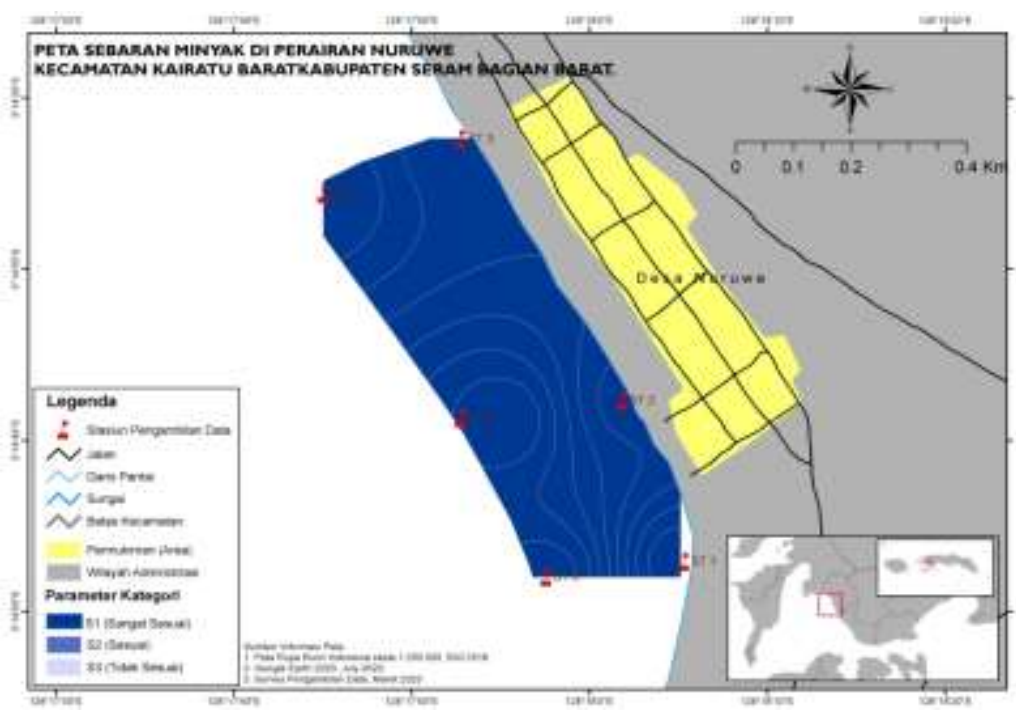

Gambar 14. Peta analisa kesesuaian minyak

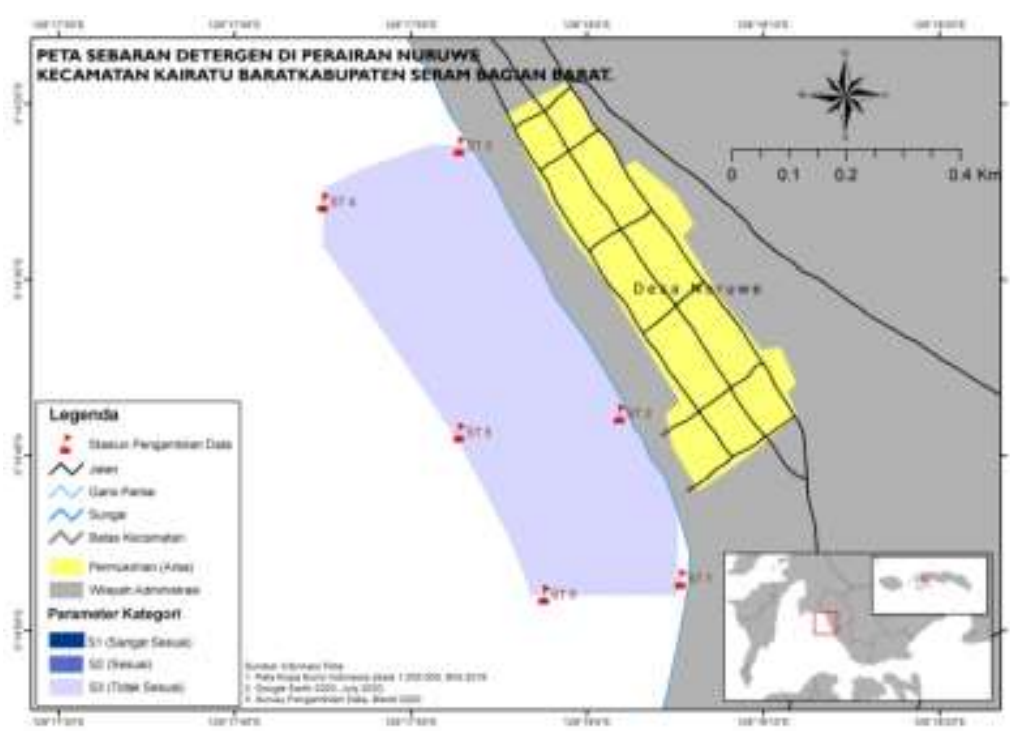

Gambar 15. Peta analisa kesesuaian deterjen

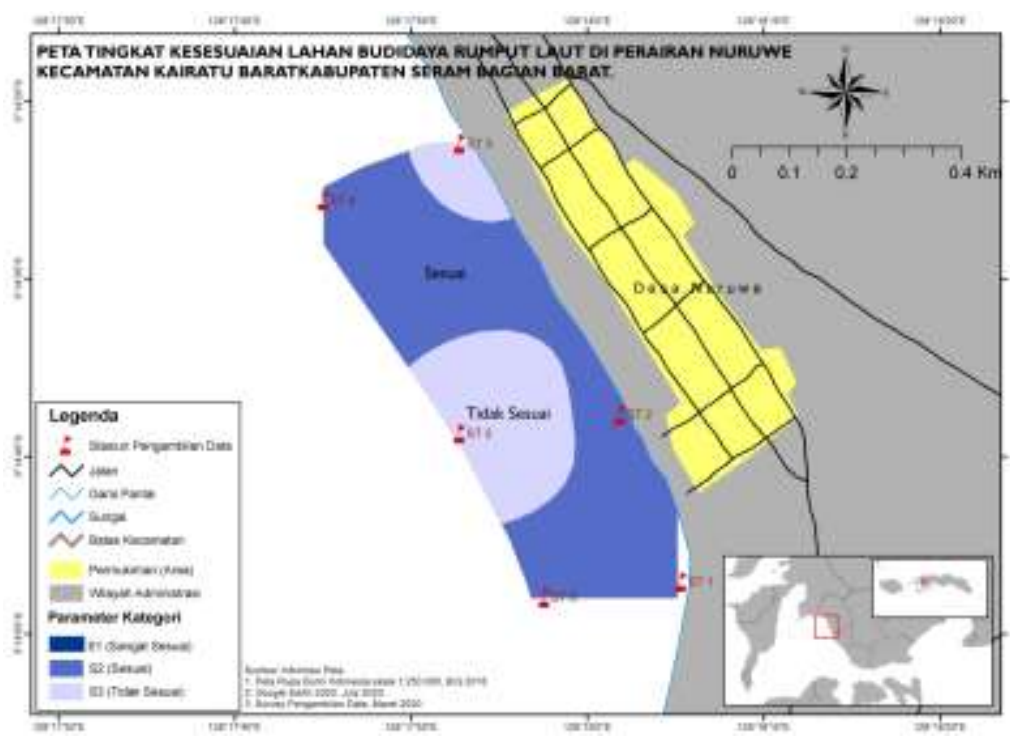

Gambar 16. Peta lokasi kesesuaian lahan untuk budidaya rumput laut dengan sistem longline 


\section{KESIMPULAN DAN SARAN}

Berdasarkan hasil penelitian yang dilakukan di Perairan Nuruwe dan dari pembahasannya dapat disimpulkan sebagai berikut:

1. Parameter kualitas air sangat mendukung atau layak untuk mendukung kegiatan budidaya sistem longline di perairan Nuruwe.

2. Kesesuaian lahan budidaya rumput laut dengan sistem longline di perairan Nuruwe tergolong sesuai (S2). Luasan lahan yang efektif sebesar \pm 10 ha dengan jumlah sebanyak 20 unit longline.

Saran yang dapat diberikan yaitu perlu adanya kebijakan pemerintah baik Pemerintah Provinsi maupun Kabupaten SBB dalam mengatur pengembangan kawasan budidaya rumput laut di perairan pesisir dan dalam pelaksanaanya harus melibatkan masyarakat untuk berperan lebih aktif. Perlu dilakukan penelitian lanjutan tentang evaluasi dan monitoring kegiatan budidaya yang telah dilakukan khususnya perubahan kualitas air, sehingga permasalahan yang muncul dapat diatasi. Perlu juga dilakukan penelitian tentang teknologi terbaik untuk menghasilkan produksi yang baik pula.

\section{DAFTAR PUSTAKA}

Adipu, Y., Lumenta. C., Kaligis. E., Sinjal. H.J. 2013. Kesesuaian Lahan Budidaya Laut Di Perairan Kabupaten Bolaang Mongondow Selatan Sulawesi Utara. Jurnal Perikanan dan Kelautan Tropis. Vol IX-1: 19-26. DOI: https://doi.org/ 10.35800/jpkt.9.1.2013.3448.

Akib, A., M. Litaay, Ambeng dan M. Asnady. 2015. Kelayakan Kualitas Air untuk Kawasan Budidaya Eucheuma Cottoni Berdasarkan Aspek Fisika, Kimia dan Biologi di Kabupaten Kepulauan Selayar. Jurnal Pesisir dan Laut Tropis. 1(1): 25-36. DOI: 10.35800/jplt.3.1. 2015.9203.

Amarullah. 2007. Pengelolaan Sumberdaya Perairan Teluk Tamiang Kabupaten Kota baru Untuk Pengembangan Budidaya Rumput Laut (Eucheuma Cottonii). Tesis. Program Pascasarjana IPB. Bogor.

Anggadiredja, J.T, A. Zantika, H. Purwoto, S. Istini. 2006. Rumput Laut. Penebar Swadaya. Jakarta.
Ariyati, R.W., L. Syah'rani, dan E. Arini. 2007. Analisis Kesesuaian Perairan Pulau Karimunjawa dan Pulau Kemujan sebagai Lahan Budidaya Rumput Laut Menggunakan Sistim Informasi Geografis. Jurnal Pasir Laut 3(1): 27-45.

Borolla, D. 2011. Pengembangan Kawasan Budidaya Ikan Dan Rumput Laut Di Perairan Kaibobo Berbasis Kesesuaian Dan Daya Dukung. Tesis. Program Pascasarjana Unpatti. Ambon.

Bountyfa. M., A. Alamsjah, S. Subekti. 2012. Pengaruh Medium Yang Tercemar Deterjen Terhadap Pertumbuhan, Kandungan Alginat Dan Klorofil Sargassum Sp. Journal of Marine and Coastal Science 1(1), 13 - 21.

Burase. H., Rompas. R.J., Ngangi. E.L.A. 2013. Kesesuaian Areal Budidaya Rumput Laut Berdasarkan Kapasitas Perairan Desa Arakan Kabupaten Minahasa Selatan. Budidaya Perairan 1(1): 27-35 DOI: https://doi.org/10.35800/bdp.1.1.2013.7 28.

Fadli, R. Pambudy, Harianti. 2017. Analisis Daya Saing Agribisnis Rumput Laut di Kabupaten Lombok Timur. Jurnal Agribisnis Indonesia 5(2): 89-102. E-ISSN 2579-3594.

Gufana, S.S.M., Fendi. F., Karyawati. K., Sommeng, A. 2017. Kajian Kesesuaian Lokasi Perairan Untuk Budidaya Rumput Laut di Kabupaten Muna,Indonesia. Jurnal Akuakultur Pesisir dan Pulau-Pulau Kecil 1(2): 13-24 E-ISSN 2598-8298.

Hikmah. 2015. Strategi Pengembangan Industri Pengolahan Komoditas Rumput Laut $E$. Cottonii untuk Peningkatan Nilai Tambah di Sentra Kawasan Industrialisasi. Jurnal Kebijakan Sosek KP 5(1): 27-36.

Kementerian Kelautan dan Perikanan. 2018. Laporan Tahunan 2018. Jakarta.

Kementerian Lingkungan Hidup. 2004. Keputusan Menteri Lingkungan Hidup Nomor 51 tentang Baku Mutu Air Laut. Jakarta.

Khasanah, U. 2013. Analisis Kesesuaian Perairan Untuk Lokasi Budidaya Rumput Laut Eucheuma cottonii Di Perairan Kecamatan Sajoanging Kabupaten Wajo. Skripsi. Ilmu Kelautan Universitas Hassanudin. Makassar.

Maryunus, R.P., J. Hiariey, Y. Lopulalan. 2018. Faktor Produksi dan Perkembangan Produksi Usaha Budidaya Rumput Laut Kotoni di Kabupaten Seram Bagian Barat. Jurnal Sosek KP 13(2): 179-192.

Maufilda. 2015. Kandungan BOD, COD, TSS, pH dan Minyak atau Lemak pada Air Limbah Di 
Inlet Dan Outlet Industi Cold Storage Udang (Studi Di PT. Panca Mitra Multi Perdana Kapongan-Situbondo). Skripsi. Universitas Jember.

Mira. 2012. Insentif Ekonomi Terhadap Usaha Aquaculture. Jurnal Ekonomi Pembangunan 13(2): 235-246.

Nurwidodo, A. Rahardjanto, Husamah, M. Odi, A. Mufrihah. 2017. Potenis, Kendala, dan Strategi Pengembangan Budidaya Rumput Laut Berbasis Kolaborasi di Daerah Kepulauan Sapeken Kabupaten Sumenep. Prodising Seminar Nasional III "Biologi, Pembelajaran, dan Lingkungan Hidup Perspektif Interdisipliner". Diselenggarakan oleh Prodi Pendidikan Biologi-FKIP bekerjasama dengan Pusat Studi Lingkungan dan Kependudukan (PSLK) Universitas Muhammadiyah Malang, 29 April 2017. http://research-report.umm.ac.id/ index.php/.

Pongmasak, P.R, Hasnawi, A.M. Pirzan, M. Lanuru. 2010. Analisis Kesesuaian Lahan Untuk Pengembangan Budidaya Rumput Laut Di Gusung Batua Pulau Badi Kabupaten Pangkep Sulawesi Selatan. J. Riset Akuakultur 5(2): 299-316.

DOI: http://dx.doi.org/10.15578/jra.5.2.2010.2 99-316.

Rangka, N. A dan M. Paena. 2012. Potensi Dan Kesesuaian Lahan Budidaya Rumput Laut (Kappaphycus alvarezii) Di Sekitar Perairan Kabupaten Wakatobi Provinsi Sulawesi Tenggara. Jurnal Ilmiah Perikanan dan Kelautan Vol. 4 No. 2.

Ramdhan. Y.M., Prihantono. J., Gunawan. D., Saepuloh. D., Salim. H.L., Rizaki. I. Zahara. R.I. 2017. Pengelolaan Budidaya Rumput Laut Berbasis Daya Dukung Lingkungan Perairan Di Pesisir Kabupaten Dompu, Provinsi NTB. Seminar Nasional Geomatika 2017: Inovasi Teknologi Penyediaan
Informasi Geospasial Untuk Pembangunan Berkelanjutan. Jakarta. DOI: http://dx.doi.org/10.24895/SNG.2017.20.391 .

Risnawati, m. Kasim, Haslianti. 2018. Studi Kualitas Air Kaitannya Dengan Pertumbuhan Rumput Laut (Kappaphycus alvarezii) pada Rakit Jaring Apung di Perairan Pantai Lakeba Kota Bau-Bau Sulawesi Tenggara. Jurnal Manajemen Sumber Daya Perairan 4(2): 155164. E-ISSN 2503-4286.

Santoso, L. \& Y. T. Nugraha. 2008. Pengendalian Penyakit Ice-Ice untuk Meningkatkan Produksi Rumput Laut Indonesia. Jurnal Saintek Perikanan 3(2): 37-43.

Schaduw, J. N. W. \& E. Ngangi. 2015. Karakteristik Lingkungan Perairan Teluk Talengen Kabupaten Kepulauan Sangihe sebagai Kawasan Budidaya Rumput Laut (Kappaphycus alvarezii).

Soselisa, A. 2006. Kajian Pengelolaan Sumberdaya Pesisir Dan Laut Gugusan Pulau-Pulau Padaido Distrik Padaido Kabupaten Biak Numfor Papua. Disertasi. Program Pascasarjana IPB. Bogor.

Sugandi, W. K. \& G. M. D. Putra. 2017. Model Pengembangan Usaha Budidaya Rumput Laut (Eucheuma cottonii) dengan Pendekatan Causal Loop Diagram (Studi Kasus di Pantai Cipatujah Kabupaten tasikmalaya). Jurnal Ilmiah Rekayasa Pertanian dan Biosistem 5(1): 321-329.

Tangko. A.M. 2008. Potensi dan Prospek serta Permasalahan Pengembangan Budidaya Rumput Laut di Provinsi Sulawesi Selatan. Media Akuakultur 3(2): 137-144.

Ulqodry, T.Z., Yulizman. Syahdan, M., Santoso. 2010. Karateristik dan Sebaran Nitrat, Fosfat, dan Oksigen terlarut di Perairan Karimunjawa Jawa Tengah. Jurnal Penelitian Sains 13(1): $35-41$. 